\title{
Infrastruktuuriparannusten vaikutukset Etelä-Pohjanmaan ja Pohjois- Karjalan aluetalouksiin
}

\author{
Nina Hyytiä \\ Maa- ja elintarviketalouden tutkimuskeskus, Luutnantintie 13,00410 Helsinki,nina.hyytia@mtt.fi
}

Kuljetuskustannukset ovat yksi tärkeimmistä tekijöistä, jotka määrittävät ja rajoittavat yritysten sijoittumista ja menestymisen edellytyksiä syrjäisillä alueilla. Infrastruktuurin kohentaminen on nostettu keskeiseksi keinoksi edistämään syrjäisempien alueiden kilpailukykyä, vähentämään alueiden välistä epätasa-arvoa ja edistämään taloudellista ja sosiaalista koheesiota. Infrastuktuurin parantaminen onkin keskeinen politiikkatavoite alueellisella, kansallisella ja Euroopan Unionin tasolla.

Tässä tutkimuksessa tarkastellaan kahden suhteellisen syrjäisen maaseutualueen EteläPohjanmaan ja Pohjois-Karjalan välisiä eroja kuljetuskustannusten laskiessa ja/tai infrastruktuurin parantuessa. Koko maakuntien lisäksi tarkastellaan eroja maakuntien keskusten Seinäjoen ja Joensuun ja näitä ympäröivän muun maakunnan välillä. Yhtenä tavoitteena on selvittää, menevätkö hyödyt parannuksista kaupunkikeskuksiin vai maseutualueille. Politiikka- ja muita vaikutuksia ja eroja maaseutu- ja kaupunkialueilla analysoidaan numeerisen, yleisen tasapainon -mallin avulla. Mallin pohja-aineistona ovat maaseutualueen ja kaupunkialueen erottelevat sosiaalisen tilinpidon matriisit.

Infrastruktuurin parannuksia ei tässä tutkimuksessa mallinnettu antamalla sektoreille suoria tukia vaan sitä vastoin etsittiin mekanismeja, jotka vaikuttaisivat yritysten kustannuksiin siten, että politiikkatoimilla olisi pysyviä vaikutuksia. Tuloksia esitellään kahdesta erilaisesta simulaatiosta. Ensimmäisessä simulaatiossa koko kuljetussektorin tehokkuutta on parannettu nostamalla CEStuotantofunktion ns. tehokkuusparametrin arvoa 10\%. Toisessa simulaatiossa kaikkien sektoreiden kuljetuskustannuksia on laskettu $10 \%$. Maakuntia ja kaupunki-ja maaseutualueita vertaillaan mm. alueellisen arvonlisäyksen, investointien, työllisyyden, pääoman korkojen, tuotannontekijätulojen, paikallisen tuotannon, viennin, tuonnin, verojen ja kotitaluksien kulutuksen avulla. Sektoreita tarkastellaan erikseen ja alkutuotantoon, teollisuuteen ja palveluihin aggregoituina.

Tehokkuuden parantaminen antoi samansuuntaisia tuloksia kummastakin maakunnasta. Alueellinen arvonlisäys nousi kummassakin maakunnassa kuitenkin niin, että Etelä-Pohjanmaalla kaupunkialue hyötyi maaseutualuetta enemmän kun taas Pohjois-Karjalassa suurempi hyöty tuli maaseudulle. Työllisyys parani kummassakin maakunnassa. Kuljetuskustannusten alentaminen sen sijaan vaikutti eri tavoin Etelä-Pohjanmaalla ja Pohjois-Karjalassa johtuen mm. alueiden erilaisesta elinkeinorakenteesta. Etelä-Pohjanmaalla maaseutualue hyötyi, mutta kaupunkialueella arvonlisäys laski hieman. Pohjois-Karjalassa tulos oli päinvastainen. Kuljetuskustannusten lasku mahdollisti raaka-aineiden ja alhaisen jalostusasteen tuotteiden viemisen makunnan ulkopuolelle. Vienti lisääntyi, mutta paikalliset myyntimäärät laskivat. Aikaisempien tutkimusten tapaan infrastuktuuriparannuksilla ei saatu yksiselitteisiä ja samansuuntaisia vaikutuksia eri maakunnissa, vaan erilaiset toimenpiteet ja alueiden elinkeinorakenteen ja sijainnin erilaisuus vaikuttivat lopputuloksiin merkittävästi.

Asiasanat: aluepolitikka, kuljetuskustannukset, infrastruktuuri, yleisen tasapainon malli 


\section{Effects of transport infrastructure improvements on the regional economies of Southern Ostrobothnia and North Karelia}

\section{Introduction}

Transportation costs are considered one of the major factors in guiding the location decisions of enterprises and determining how the enterprises are managing and surviving in the long run in remote areas. Consequently, infrastructure investments have become essential political expedients in improving competitiveness, reducing regional disparities and thus promoting both social and economic cohesion.

Both in Finland and in the European Union transport infrastructure improvements are an important area where development funding has been channelled. Already during the programming period 2000-2006 the EU directed over 34\% of cohesion policy spending on transport infrastructure improvements, and still in the period 2007-2013 transport infrastructure investments are significant elements of the EU cohesion policy (European Commission 2007, 2008).

The main goal of the regional policy of Finland is to ensure balanced development of the entire country. In order to attain this goal, policy measures that are able to remove regional disparities are required. According to (Finnish municipalities 2009) the most important actions of the central government bodies of a point of view of regional development are infrastructure improvements, knowhow development, promoting enterprise competitiveness and operational environment and to secure the functioning of the labour market.

From a theoretic point of view, Losch(1959) has concluded that location patterns are determined by factor and transport costs. Later on, representatives of the new economic geography have analysed the reasons why a reduction in transport cost can lead to agglomeration. However, they have emphasized that also other factors, such as factor endowments and prices, the economies of scales, amenities, spatial spillovers and imperfect competition influence economic agglomeration or dispersion. Fujita et al (1999) list agglomerating and dispersing forces as follows: Linkages, thick markets, and knowledge spillovers and other pure external economies represent centripetal (agglomerating) forces, whereas immobile factors, land rents, commuting, and congestion and other pure diseconomies represent centrifugal (dispersing) forces.

This study aims at considering how the transport infrastructure improvements impact on the regional economies of two rural and remote regions in Finland, and in addition to consider are the resulting effects more favourable to the rural or local urban areas of these regions and in addition, do transport improvements increase or decrease agglomeration in the rural regions in Finland since international transport infrastructure studies has given ambiguous and even contradictory results (i.e. Kilkenny 1998a, 1998b; Lofgren and Robinson 1999; Holl 2004; ESPON 2005).

\section{Data and methods}

According to Pyatt and Round (1985), a Social Accounting Matrix represents macroeconomic and mesoeconomic accounts of a socioeconomic system by capturing the transactions and transfers between the economic agents included in that particular system. A SAM aims at recording and portraying all the economic activities, such as consumption, production, accumulation, and distribution taking place during an accounting period. In this research, the general structure of the SAM aims at capturing the rural-urban linkages of the regions.

Statistics Finland's regional input-output tables, relating to year 2002, were used as a core information in building the SAMs for North Karelia and Southern Ostrobothnia. These tables also served as control totals for disaggregated accounts. The disaggregation based on information collected from several secondary data sources, and also survey findings. In the end, the SAMs were balanced by using a cross entropy method (Robinson et al. 2000).

The North Karelia SAM includes 27 accounts of rural activities and 23 accounts for urban activities. Respectively, the Southern Ostrobothnia SAM has 27 accounts for rural and 25 of urban activities. The commodities accounts are not spatially disaggregated. Both SAMs include ten different factor accounts. The accounts are spatially distinguished according to the rural/urban industry shares. Labour factor division is two- fold: white collar and rural blue collar workers in rural and urban areas. Correspondingly, the capital accounts are distributed as follows: rural capital, urban capital and agricultural capital. Agricultural land factor is separated and finally accounts for rural housing rent and 
urban housing rent are distinguished. In addition, there are six different household groups, accounts for government, rest of the world and finally, account for savings and investments.

Wing (2004) characterises computable general equilibrium models (CGE) as simulations that are combining the abstract general equilibrium structure with realistic economic data in order to solve numerically for the levels of supply, demand and price supporting equilibrium across a specified set of markets. Thus Walrasian general equilibrium is prevailed as supply and demand are equalized across the interconnected markets in the economy described by the model. The CGE model used in this research draws on the IFPRI:s standard stationary general equilibrium framework (Lofgren et al. 2002).

The model comprises of a set of linear and nonlinear simultaneous equations that determine behaviour of the economic agents in the model. These equations also include a set of macroeconomic constraints that cover factor and commodity markets, balances for government, current accounts and savings and investments. The social accounting matrices are used, not only the base year data for the CGE model, but also to calibrate the coefficients of the model equations together with production, trade and consumption elasticities. The elasticities were drawn from the previous Finnish research (Törmä and Rutherford 1992; Törmä, Rutherford and Vaittinen 1995; Vaittinen 2004; Törmä 2006).

\section{Results}

The aim of the study was to simulate permanent and indirect economic impacts caused by infrastructure improvements. Accordingly, subsidies directed straight to transportation industries are not simulated here. Explicit transportation sectors were included in the SAMs in order to enable the consideration of the impacts of changes in transportation costs and infrastructure improvements on the distribution of economic activity between the rural and urban areas in North Karelia and Southern Ostrobothnia. Each transportation activity summarises transactions of transportation, telecommunication, postal services and travel agency services, thus following the structure of Statistics Finland's regional inputoutput tables (TOL2002).

Two different simulations were carried out. Firstly, a $10 \%$ growth in total productivity of transportation sectors was modeled as a change in the efficiency parameter in the CES activity function. In the second simulation, transportation costs of every sector were cut for $10 \%$. This implies that demand for the transportation services decline and thus the output of transportation sectors also decline. The relative importance of transportation sectors affects on the total impact that the simulation will have. The effects of the changes are measured in percentage changes of economic indicators.

First, the aggregate, regional level effects of the simulations are considered. In addition to the percentage changes the original base values of accounts are presented in the tables. This gives an opportunity to compare the relative sizes of a particular economic indicator as well as structures of the regional economies. Both simulations i.e. 10\% efficiency improvement and 10\% cost cut are presented and compared in parallel.

Table 1. Macroeconomic indicators.

\begin{tabular}{lcccccc} 
& \multicolumn{2}{c}{ Southern Ostrobothnia } & \multicolumn{3}{c}{ North Karelia } \\
& $\begin{array}{c}\text { BASE } \\
\text { milj. } €\end{array}$ & $\begin{array}{c}\text { Efficiency } \\
\text { improvement }\end{array}$ & $\begin{array}{c}\text { Cost cut } \\
\text { BASE } \\
\text { milj. } €\end{array}$ & $\begin{array}{c}\text { Efficiency } \\
\text { improvement }\end{array}$ & Cost cut \\
Absorption & 4066,79 & 2,47 & $-4,8$ & 3583,99 & 2,99 & $-2,42$ \\
Private Consumption & 2448,79 & 1 & 0,83 & 2036,25 & 1,38 & 0,48 \\
Investments & 718,55 & 10,58 & $-30,03$ & 630,52 & 12,55 & $-15,32$ \\
Exports & 2442,42 & $-0,04$ & 7,07 & 1888,51 & 1,01 & 3,89 \\
Imports & 2534,21 & 1,41 & $-2,05$ & 2047,64 & 2,83 & $-1,7$ \\
GDP at Market Price & 3975 & 1,61 & 0,74 & 3424,85 & 1,99 & 0,63 \\
NetITAX & 550,53 & 2,47 & $-2,29$ & 493,16 & 2,51 & $-1,21$ \\
GDP at Factor Costs & 3424,46 & 1,51 & 0,26 & 2931,69 & 1,94 & $-0,04$
\end{tabular}

Southern Ostrobothnia is larger economy measured in any of the indicators above. Generally, changes are going to the same direction in both of the regions. However, there are also differences. The effects of efficiency improvement are stronger in North Karelia compared to Southern Ostrobothnia. On the 
contrary, the cost cut simulation shows larger effects on Southern Ostrobothnia. Especially investments respond strongly in Southern Ostrobothnia showing a surprising 30\% cut in investments as transportation costs are decreased by $10 \%$. GDP measured at market price shows positive total impact for both of the regions and simulations, whereas GDP at factor costs shows negative total following the transportation cost cut in North Karelia. With help of following tables as well as activity-specific results these results are further considered and specified.

First, the GDP effects measured at factor costs are further considered. Here the activities are aggregated to primary, secondary and tertiary, such that secondary relates to manufacturing and tertiary to services sectors in the rural and urban areas. Table 2 shows that the regional GDP of primary sectors are falling as efficiency of transportation sectors is improved. Further consideration is showing that figures for agriculture in both of the regions are slightly positive. The corresponding figures for forestry are $-5 \%$ for Southern Ostrobothnia and $-2,6 \%$ for North Karelia. Secondary and especially tertiary sectors are gaining, transportation and construction the most. In Southern Ostrobothnia the positive impacts in the urban area are bigger compared to the rural area. However, in North Karelia the situation is opposite as the rural area is gaining larger benefits. If comparing total effects between the regions, North Karelia earns higher increase measured with the regional GDP.

When comparing the results of the cost cut simulation, the regions show different total effects. Southern Ostrobothnia has positive total effect, in a way that rural area is gaining and urban area is losing, whereas in North Karelia where total effect is negative, rural area is losing and urban gaining. Primary industries are gaining in both regions, but in South Ostrobothnia rural secondary is gaining and tertiary losing whereas urban tertiary is slightly gaining but secondary clearly losing. In North Karelia, secondary sectors are gaining and tertiary losing in both rural and urban areas. Generally, textile, timber, metal and mining activities are showing growing regional GDP, whereas construction and transport sectors are facing shrinking GDP when the transportation costs were cut.

Table 2. GDP at factor costs

\begin{tabular}{lrccccc} 
& \multicolumn{2}{l}{ Southern Ostrobothnia } & \multicolumn{4}{l}{ North Karelia } \\
& BASE & $\begin{array}{c}\text { Efficiency } \\
\text { milj.€ }\end{array}$ & $\begin{array}{c}\text { improvement } \\
\text { Rural }\end{array}$ & $\begin{array}{c}\text { Cost cut } \\
\text { BASE }\end{array}$ & $\begin{array}{c}\text { Efficiency } \\
\text { mimprovement }\end{array}$ & Cost cut \\
Primary & 460,4 & $-1,1$ & 2,19 & 348,8 & $-1,09$ & 2,98 \\
Secondary & 796,64 & 0,69 & 2,67 & 523,8 & 2,33 & 0,33 \\
Tertiary & 1330,21 & 2,61 & $-1,57$ & 858,5 & 3,14 & $-1,62$ \\
Urban & 837,21 & 1,98 & $-0,19$ & 1207,7 & 1,76 & 0,08 \\
Primary & 15,22 & $-3,29$ & 16,56 & 0 & 0 & 0 \\
Secondary & 182,86 & 2,04 & $-3,16$ & 321,9 & 1,65 & 1,05 \\
Tertiary & 639,13 & 2,09 & 0,26 & 885,8 & 1,81 & $-0,27$ \\
TOTAL & 3424,46 & 1,51 & 0,26 & 2931,7 & 1,94 & $-0,04$
\end{tabular}

Next, attention is turned to employment effects and factor rents. Since the labour markets are integrated in the simulation the employment differences between rural and urban areas are not considered. However, the demand of different labour categories in each rural and urban industry can be considered. The total employment effects are positive excluding the supply of white collar workers in the cost cut scenario in North Karelia. In Southern Ostrobothnia demand of white collar labour in efficiency improvement directs to secondary and tertiary sectors. In North Karelia, demand of white collar employees is increased in every aggregated sector in a way that demand in rural area grows more and secondary sectors are increasing their demand the most. As for blue collar workers in Southern Ostrobothnia demand is bigger in the urban area, and secondary and tertiary sectors in both areas are increasing their demand of blue collar workers. In North Karelia demand of blue collar workers increases more in the rural area, and most in secondary sectors.

Cost cut scenario in Southern Ostrobothnia shows positive total effects on the whole region as well as for the rural area. The total effect in the urban area is negative following the negative development in the urban secondary sector. Urban primary sector becomes more competitive and thus in- 
creases the labour demand clearly. In North Karelia, demand of blue collar workers is increasing slightly, in a way that all the sectors in the urban area increase their demand whereas rural total is negative due to negative figure in the rural tertiary sector. As a conclusion, efficiency improvement simulation employment effects are clearly larger than the transportation cost cut simulation was able to create.

Capital rents increase in the efficiency improvement simulations in each of the category and both of the regions. Price of urban capital rises the most. On the contrary, as the transportation costs are cut, rents of rural and agricultural capital are rising clearly more than urban capital. Housing rents are more sensitive to cost cuts in Southern Ostrobothnia, whereas in North Karelia Efficiency improvements induce higher housing rents.

Table 3. Effects on employment and factor rents.

$\begin{array}{lcccc} & \begin{array}{c}\text { Southern Ostrobothnia } \\ \text { Efficiency } \\ \text { improvement }\end{array} & \begin{array}{c}\text { Cost cut } \\ \text { Eorth Karelia } \\ \text { Efficiency }\end{array} \\ \begin{array}{lcccc}\text { improvement } \\ \text { White collar }\end{array} & 1,3 & 0,26 & 1,9 & -0,21 \\ \text { Blue collar } & 1,48 & 0,67 & 2,28 & 0,05 \\ \text { Factor rents } & & & & \\ \text { Rural Capital } & 1,81 & 1,86 & 1,42 & 2,5 \\ \text { Agricultural Capital } & 0,88 & 4,35 & 1,41 & 2,56 \\ \text { Urban Capital } & 2,71 & -0,01 & 2,08 & 1,2 \\ \text { Rural Housing } & 1,21 & 1,48 & 1,74 & 0,88 \\ \text { Urban Housing } & 1,21 & 1,48 & 1,74 & 0,88\end{array}$

Table 4. Effects on exports, imports and domestic sales.

\begin{tabular}{|c|c|c|c|c|c|c|}
\hline \multirow[b]{2}{*}{ Exports } & \multicolumn{2}{|c|}{ Southern Ostrobothnia } & \multicolumn{3}{|c|}{ North Karelia } & \multirow[b]{2}{*}{ Cost cut } \\
\hline & $\begin{array}{l}\text { BASE } \\
\text { milj.€ }\end{array}$ & $\begin{array}{l}\text { Efficiency } \\
\text { improvement }\end{array}$ & Cost cut & $\begin{array}{l}\text { BASE } \\
\text { milj. } €\end{array}$ & $\begin{array}{l}\text { Efficiency } \\
\text { improvement }\end{array}$ & \\
\hline Primary & 168,7 & $-2,31$ & 5,99 & 165,4 & $-0,61$ & 2,53 \\
\hline Secondary & 2120,5 & $-0,93$ & 7,78 & 1554,2 & 0,15 & 4,62 \\
\hline Tertiary & 153,2 & 14,74 & $-1,56$ & 168,8 & 10,55 & $-1,51$ \\
\hline TOTAL & 2442,4 & $-0,04$ & 7,07 & 1888,5 & 1,01 & 3,89 \\
\hline \multicolumn{7}{|l|}{ Imports } \\
\hline Primary & 97,7 & 1,24 & 5,08 & 84,5 & 1,89 & 5,6 \\
\hline Secondary & 1587,3 & 2,01 & $-1,66$ & 1269,1 & 3,66 & $-1,87$ \\
\hline Tertiary & 849,3 & 0,3 & $-3,61$ & 694,1 & 1,44 & $-2,27$ \\
\hline TOTAL & 2534,2 & 1,41 & $-2,05$ & 2047,7 & 2,83 & $-1,7$ \\
\hline \multicolumn{7}{|c|}{ Domestic Sales } \\
\hline Primary & 541,9 & $-0,5$ & 1,99 & 310,2 & $-0,27$ & 4,05 \\
\hline Secondary & 972,4 & 4,55 & $-10,68$ & 782,1 & 6,03 & $-5,58$ \\
\hline Tertiary & 3049,4 & 1,69 & $-0,76$ & 2690,5 & 1,96 & $-0,75$ \\
\hline TOTAL & 4563,7 & 2,04 & $-2,55$ & 3782,7 & 2,62 & $-1,36$ \\
\hline
\end{tabular}

Efficiency improvement creates increase in exports of tertiary commodities and services whereas exports of primary commodities are decreasing in both of the regions. At the same time, imports are in- 
creasing in each aggregated sector, and domestic sales of secondary and tertiary products are increasing. Changes are larger in North Karelia compared to Southern Ostrobothnia.

Transportation cost cuts has generally opposite effects compared to the efficiency improvements in both of the areas. Exports, imports and domestic sales of primary products are increasing, and imports and domestic sales of secondary and tertiary products are decreasing. At a regional level exports are increasing in both of the regions, whereas imports and domestic sales are decreasing.

\section{Conclusions}

In this paper transport infrastructure improvements were considered from two different angles and applied to two relatively remote regions in Finland. Two approaches had quite opposite impacts on the study regions. The efficiency improvements of the transportation sectors gave positive total impacts on both of the regions in terms of the gross regional domestic product. In Southern Ostrobothnia, the urban area gained more than the rural area whereas in North Karelia the situation was opposite. Employment was increasing in both of the regions.

On the contrary, the transportation cost cut simulation gave mixed results. The total GDP effect was positive in Southern Ostrobothnia such that rural area was gaining whereas the urban area was losing. However, in North Karelia the regional total effect was slightly negative, rural total being negative and urban total being positive. The domestic sales of secondary and tertiary sectors' products were falling in both of the regions simultaneously as the exports of primary and secondary sectors' products were increasing. Thus the cut in the transportation cost enabled cheaper transportation for raw materials and other products of relatively low degree of processing to other parts of the country. In the background of the differences were different economic structures of the regions as well as the relative importance and structure of the urban areas.

Household income and consumption were increasing in both of the regions and simulations. Foreign savings were increasing in both of the regions as efficiency improvement was applied, whereas in cost cut scenarios foreign savings were decreasing drastically in both of the regions, especially in Southern Ostrobothnia. This was reflected on the regional investments, because both of the regions are relatively dependent on financial flows from outside of the regions.

These rather mixed findings support the previous research result showing that transport infrastructure investment have ambiguous effects on rural economies such that different measures can lead either to agglomeration or dispersion. 


\section{References}

ESPON 2.1.1. 2005. Territorial impacts of EU Transport and TEN Policies. Final Report. Brussels, ESPON. European Commission. 2007. Growing Regions, Growing Europe: Fourth Report on Economic and Social Cohesion. Brussels, European Commission.

European Commission. 2008. Green Paper on Territorial Cohesion: Turning Territorial Diversity into Strength. COM 616 final. Brussels, European Commission.

Fujita, M., Krugman, P. \& Venables A.J. 1999. The Spatial Economy: Cities, Regions, and International Trade. MIT Press, Cambridge.

Holl, A. 2004. Manufacturing location and impacts of road transport infrastructure: empirical evidence from Spain. Regional Science and Urban Economics 34, 341-363.

Kilkenny, M. 1998a. Transport costs and rural development. Journal of Regional Science 38, 293-312.

Kilkenny, M. 1998b. Transport costs, the new economic geography and rural development. Growth and Change 29, 259-280.

Lofgren, H., Harris, R.L. \& Robinson, S. 2002. Standard Computable General Equilibrium Model in GAMS. International Food Policy Research Institute

Lofgren, H. \& Robinson, S. 1999. Spatial Networks in Multi-Region Computable General Equilibrium Models. TMD Discussion Paper no. 35. Washington D.C. IFPRI.

Losch, A. 1959. The Economic of Location. New Haven, Yale University Press.

Pyatt. G. \& Round, J.I. (edt.) 1985. Social Accounting Matrix: A basis for planning. World Bank.

Robinson, S, Cattaneo, A \& El-Said, M. 2000. Updating and estimating a Social Accounting Matrix using cross entropy method. TMD discussion papers 59. International Food Policy Institute (IFPRI).

Törmä, H. 2006. Macroeconomic and Welfare Effects of the CAP Reform in Finland - A CGE GemRur Modelling Approach. (not published)

Törmä, H. \& Rutherford, T. 1992. A General Equilibrium Assessment of Finland's Grand Tax Reform, Reports No 15, Department of Economics and Management. University of Jyväskylä.

Törmä, H. \& Rutherford, T. 1993. Integrating Finnish Agriculture into EC's Common Agricultural Policy. Government Institute for Economic Research. VATT-Research Reports 13.

Törmä, H., Rutherford, T \& Vaittinen R. 1995. What will EU Membership and the Value-Added Tax Reform do to Finnish Food Economy? A CGE Analysis. Government Institute for Economic Research. VATTDiscussion Papers 88.

Vaittinen, R. 2004. Trade Policies and Integration: Evaluations with CGE-Models. Helsinki School of Economics, A:235.

Wing, I.S. 2004. Computable Equilibrium Models and Their Use in Economy-Wide Policy Analysis: Everything You Ever Wanted to Know (But Were Afraid to Ask). Boston University. 